\title{
Abstracts - Résumés - Zusammenfassungen
}

\author{
Hungdah Su \\ The Father of Europe in China: \\ Jean Monnet and creation of the C.D.F.C. (1933-1936)
}

Jean Monnet's adventure in China was an extension of his financial ambitions in the thirties, which were deeply frustrated in the U.S. during the Great Depression. Invited by the Chinese government, he began presenting different projects in the summer of 1933 in order to organize an international financing group for Chinese modernization. All of them proved futile owing to Japan's opposition and other powers' reluctance. The creation of the China Development Finance Corporation (C.D.F.C.) was consequently Monnet's and China's last choice, the success of which shed light on Monnet's amazing wisdom and pragmatism. In the end, he became engaged in China's construction projects to arm the country against Japan's invasion. He was, therefore, targeted by the Japanese government that never ceased to condemn his activities in China, and was thanked by the KMT government then and even the PRC later.

\section{Le père de l'Europe en Chine: \\ Jean Monnet et la création de la C.D.F.C. (1933-1936)}

L'aventure de Jean Monnet en Chine était un prolongement de ses ambitions purement financières pendant les années trente, qui avaient été sévèrement frustrées aux Etats-Unis par la Grande dépression. Invité par le gouvernement du Guomindang, il commençait à présenter des projets différents en été 1933 ayant pour objet d'organiser un groupe international censé financer la modernisation chinoise. Tous ses projets ont échoué à cause de l'opposition japonaise et de l'hésitation d'autres puissances. La création de la C.D.F.C. (China Development Finance Corporation) était par conséquence le dernier espoir de Monnet et du gouvernement chinois. Le succès de la C.D.F.C. a mis en lumière le talent et le pragmatisme de Monnet. Néanmoins, l'opération a forcé aussi Monnet à s'engager dans la construction chinoise contre l'invasion japonaise. Il était donc condamné sans arrêt par le gouvernement japonais à l'époque, et remercié par le gouvernement du Guomindang des années trente et par la Chine populaire plus tard.

\section{Der Gründervater Europas in China: Jean Monnet und die Schaffung der C.D.F.C. (1933-1936)}

Jean Monnets Chinaabenteuer in den Dreißigerjahren war Ausdruck seiner Ambition, trotz der schrecklichen Wirtschaftskrise in den USA, eine Rolle in der mächtigen Finanzwelt zu spielen. Auf Bitten der Guomindang Regierung stellte er im Sommer 1933 verschiedene Projekte vor mit dem Ziel eine internationale Investorengruppe aufzubauen die den Modernisierungsprozess in China unterstützen sollte. Das Unterfangen scheiterte aber an der heftigen Opposition Japans und der zögernden Haltung anderer Großmächte. Die Gründung der China Development Finance Corporation (C.D.F.C) war folglich Monnets letzte Hoffnung. Dies gilt auch für die Guomindang Regierung. Der Erfolg der C.D.F.C. unterstreicht übrigens ganz hervorragend das Talent und den Pragmatismus von Monnet. Nichtsdestotrotz hat das ganz Vorhaben den Franzosen in den chinesischen Abwehrkampf gegen Japan verstrickt. Er wurde denn auch demzufolge ständig von der japanischen Regierung verurteilt, wohinge- 
gen der Guomindang, und dreißig Jahre später, sogar die Volksrepublik China ihm für seine Bemühungen dankten.

\section{Anne Boerger-De Smedt Beyond the numbers. Revisiting the composition of the European Commission}

Bound by the Treaty of Nice which provides that the composition of the European Commission will have to be revised with the addition of the $27^{\text {th }}$ Member State, the European Union countries today have to reexamine a sensitive question of the institutional configuration of the Union. Even if they admit that the Commission represents the European interests, these countries, both large and small, have never been keen on the idea of periodically giving up the presence of one their nationals in Brussels. Their reservations are not new. They were, in fact, expressed right at the creation of the institutions of the first European Communities in the fifties. The objective of this article is to shed light on the question of the composition of the European Executive from the historical point of view. It analyzes the debates which developed on this subject during the negotiations of ECSC, the EDC, the EEC and Euratom to explain how, from their very genesis, the Six were unable to create an executive body which did not include at least one national of each Member State.

\section{Derrière la valse des chiffres. Retour sur les origines de la composition de l'exécutif européen}

Liés par le Traité de Nice qui prévoit que la composition de la Commission européenne devra être revue à la baisse dès l'adhésion du $27^{\mathrm{ème}}$ Etat membre, les pays de l'Union européenne sont aujourd'hui appelés à rouvrir un dossier sensible du fonctionnement institutionnel de l'Union. Même s'ils admettent que la Commission défend avant tout les intérêts européens, ces pays, petits ou grands, ne sont guère séduits par l'idée de renoncer périodiquement à la présence d'un de leurs nationaux à Bruxelles. Leurs réticences ne sont cependant pas nouvelles. Elles se sont en effet exprimées dès la création des institutions communautaires dans les années cinquante. L'objectif de cet article est de replacer la question de la composition de l'Exécutif européen dans une perspective historique. Il analyse les débats qui se sont développés à ce sujet durant les négociations de la CECA, de la CED, de la CEE et de l'Euratom pour expliquer comment, dès les origines, les Six ont été incapables de créer un organe exécutif qui ne comprenait pas au moins un citoyen de chaque Etat-membre.

\section{Zahlenwalzer. \\ Über die Mandatsverteilung in der frühen europäischen Exekutive}

Durch den Vertrag von Nizza - er besagt, dass die Zahl der Mandate innerhalb der europäischen Kommission nach unten revidiert werden muss sobald das 27. Mitgliedsland aufgenommen wird - sind die Staaten der Europäischen Union genötigt die brisante Akte des institutionellen Aufbaus der Gemeinschaft erneut zu öffnen. Auch wenn die Mission der Kommissare als Verfechter vordergründig europäischer Interessen gerne in den Vordergrund gestellt wird, so ändert dies dennoch kaum etwas am Umstand, dass die einzelnen EU-Länder, egal ob groß oder klein, sich nur sehr ungern mit dem Gedanken anfreunden in Zukunft zeitweise nicht mehr mit einem ihrer Landsleute in Brüssel vertreten zu sein. Ihre Ängste und Befürchtungen sind allerdings nicht neu. Ganz im Gegenteil. Es gibt sie seit der Gründung der Gemeinschaft in den frühen Fünfzigerjahren. Der vorliegende Aufsatz stellt die 
Frage der Zusammensetzung der europäischen Exekutivorgane in eine historische Perspektive und analysiert die Debatten, die seinerzeit im Rahmen der EGKS-, EVG, EWG, und Euratom-Verhandlungen aufgeworfen wurden. Schon damals war es unmöglich gewesen, sich auf ein Exekutivorgan zu verständigen in dem nicht wenigstens ein Vertreter pro Mitgliedstaat vorgesehen war.

\section{Henning Türk \\ The grand coalition in West Germany and Great Britain's second application to join the European Communities, 1966-1969}

The second British application for membership to the European Communities was a central theme of European integration in the second half of the 1960s. The grand coalition that ruled Western Germany from 1966 to 1969 played a decisive role in the debate about the application. In front of its partners and of public opinion, the German government claimed the position of an "honest broker" between the application candidates and their supporters on the one side and the French opponent on the other. Current historical research largely follows this self-presentation. However, an analysis of the internal decision-making process shows that the German government was divided on the British question. Choosing to be an "honest broker" thus not only had the advantage of causing the least possible irritation in Germany's partners but also of leaving aside the differences of opinion on European policy as well as the conflict of objectives within the German government. However, the differing viewpoints on British accession came to the fore and hampered West Germany's self-imposed role of mediator.

\section{La grande coalition d'Allemagne fédérale et la seconde candidature britannique aux Communautés Européennes, 1966-1969}

La deuxième demande d'adhésion britannique à la Communauté des Six était un thème central de la construction européenne pendant la seconde moitié des années soixante. La grande coalition qui gouvernait la RFA de 1966 à 1969 jouait à cet égard un rôle décisif. Face à ses partenaires et face à l'opinion publique, le gouvernement fédéral revendiquait la mission de l' "honnête courtier» entre d'une part les pays candidats et ceux des Etats membres de la Communauté qui les soutenaient, et d'autre part la France. La recherche historique a jusqu'ici largement fait sienne cette manière de Bonn à décrire les choses. Or, une analyse du processus décisionnel montre toutefois que le gouvernement fédéral était divisé sur la question de l'adhésion britannique. Le rôle librement choisi de l'«honnête courtier» avait donc non seulement l'avantage de ne pas irriter les autres pays, mais aussi d'effacer les divergences d'opinions en matière de politique européenne et d'estomper les conflits au sein de la grande coalition en ce qui concerne les objectifs à poursuivre. Pourtant la résurgence permanente des différends internes au sujet de l'adhésion britannique rendait particulièrement délicate l'exécution de la mission de l'honnête courtier que la grande coalition s'était elle-même attribuée.

\section{Die Große Koalition in der Bundesrepublik Deutschland und das zweite britische Beitrittsgesuch zu den Europäischen Gemeinschaften, 1966-1969}

Das zweite britische Beitrittsgesuch zu den Europäischen Gemeinschaften war ein Schlüsselthema der europäischen Integration in der zweiten Hälfte der 1960er Jahre. Eine zentrale Rolle spielte hierbei die Regierung der Großen Koalition in der Bundesrepublik Deutsch- 
land, die zwischen 1966 und 1969 amtierte. Gegenüber den Partnerländern und der Öffentlichkeit reklamierte die Bundesregierung die Rolle des „ehrlichen Maklers“ zwischen den Beitrittskandidaten und ihren Unterstützern auf der einen sowie dem Beitrittsgegner Frankreich auf der anderen Seite. Diese Selbstetikettierung wurde von der historischen Forschung bisher weitestgehend übernommen. Eine Analyse des internen Entscheidungsprozesses zeigt jedoch, dass die Bundesregierung in der Frage eines britischen Beitritts gespalten war. Die selbstgewählte Rolle als ,ehrlicher Makler“ bot somit den Vorteil, nicht nur die anderen Länder so wenig wie möglich zu verärgern, sondern auch die europapolitischen Meinungsverschiedenheiten und Zielkonflikte innerhalb der Bundesregierung auszuklammern. Dass sich die unterschiedlichen Sichtweisen auf einen britischen Beitritt immer wieder Bahn brachen, erschwerte jedoch die selbstgewählte Vermittlerrolle.

\section{Christian Henrich-Franke \\ From a Supranational Air Authority to the Founding of the European Civil Aviation Conference (ECAC)}

The paper deals with a rather unknown aspect of European integration, the attempts at integrating the civil aviation sector in the early 1950s. The aim is to explain why the ambitious proposal to create a supranational European air authority in 1951 was completely altered after four years of discussion. With the adoption of a resolution constituting the European Civil Aviation Conference (ECAC) an isolated organisation without any competence took up its work to discuss administrative and technical aspects of European civil aviation. This outcome was caused by a coincidence of a variety of factors ranging from negative interactions with the overall (political and economic) integration process in Europe to national politicians regarding airline companies as national symbols which called for protection.

\section{D'une autorité supranationale de l'aviation à la fondation de la Conférence Européenne de l'Aviation Civile}

La contribution est focalisée sur un aspect d'ordinaire peu connu de l'intégration européenne, à savoir les efforts entrepris au début des années cinquante pour intégrer l'aviation civile. Pourquoi la proposition ambitieuse, formulée en 1951, de créer une autorité supranationale de l'aviation a-t-elle finalement débouché quatre années plus tard sur un projet d'intégration fondamentalement différend? Avec l'adoption de la résolution sur la constitution d'une Conférence Européenne de l'Aviation Civile il a été procédé à la formation d'un nouvel organisme isolé des autres institutions européennes, sans pouvoirs décisionnels et exclusivement compétent pour discuter des seuls aspects administratifs et techniques de l'aviation civile en Europe. Il y a à cela plusieurs raisons. Elles s'étendent de l'interdépendance négative avec les objectifs supérieurs du processus d'intégration (politique et économique) en Europe aux réticences des hommes politiques nationaux qui entrevoyaient en les compagnies aériennes des objets de prestige national et que partant, il s'agissait de mettre à l'abri des partenaires européens.

\section{Von einer supranationalen Luftfahrtbehörde zur Gründung der Europäischen Zivilluftkonferenz}

Der Aufsatz beschäftigt sich mit einem eher unbekannten Aspekt der Europäischen Integration, den Bemühungen um eine Integration der zivilen Luftfahrt in den frühen 1950er Jah- 
ren. Es soll erklärt werden, warum diese 1951 mit dem ambitionierten Vorschlag der Gründung einer supranationalen europäischen Luftfahrtbehörde aufgenommen Bemühungen schließlich 1955 ein fundamental gewandeltes Integrationsprojekt hervorbrachten. Mit der Annahme einer Resolution über die Konstituierung der Europäischen Zivilluftkonferenz wurde eine von anderen europäischen Institutionen isolierte Organisation geschaffen, die über keinerlei Entscheidungskompetenzen verfügte und lediglich administrative und technische Aspekte der zivilen Luftfahrt in Europa diskutierte. Eine Reihe von Faktoren können hierfür angeführt werden: beginnend mit negativen Interdependenzen mit dem übergeordneten (politischen wie ökonomischen) Integrationsprozess in Europa und endend bei nationalen Politikern, die Luftfahrtgesellschaften als nationale Symbole betrachteten, die es zu schützen galt.

\section{David Burigana \\ Will Europe fly? \\ The Launching of Airbus and the Sabordement of the "Communitarian" Aeronautical Cooperation (1965-1978)}

Airbus is only one of the European cooperated programs launched in the middle of the 1960s by military and civil aircraft industries. In front of American leadership, national industries had to produce "European aircrafts" to assure their survival as independent producers, and above all designers. Then trans-national cooperation becomes the principal activity of aerospace concentrations which European countries are creating at national level at the end of the Sixties. In the 1970s economic crisis, the weakening of US competitiveness, and Britain joining EEC quicken the debate on a future "European air space", a sort of aeronautical "Common Market" living on the orders by airlines and armed forces of EEC member states. Such a project will not succeed. In 1978, Britain comes back to Airbus, Spain remains, and large orders by Eastern Airlines suggest to launch a second model. The "French Aérobus" becomes the "European Airbus" but, before "Common" way, European governments choose to realize their "Aeronautical Europe" by means of trans-national cooperation. Then, from a historical point of view, the launch of Airbus allows to perceive the trajectory of a European construction process which proceeds between integration and intergovernmental ways.

\section{L'Europe, s'envolera-t-elle? \\ Le lancement d'Airbus et le sabordage d'une coopération aéronautique «communautaire» (1965-1978)}

Airbus est seulement une des coopérations européennes lancées dans le milieu des années 1960 dans l'industrie aéronautique tant civile que militaire. Face au leadership américain, les industries nationales devaient produire des «avions européens» afin d'assurer leur survie en termes de production, mais aussi et surtout de conception. La coopération transnationale devient alors la principale activité des concentrations aérospatiales que les pays européens créent au niveau national à la fin des années Soixante. L'affaiblissement de la concurrence américaine, la crise économique et l'entrée de la Grande-Bretagne dans la CEE accélèrent au cours des années 1970 le débat sur un future «espace aérien européen», une sorte de «Marché commun» de l'aéronautique à nourrir grâce aux commandes des compagnies aériennes et des forces armées des pays membres de la Communauté. Un tel projet n'aboutit toutefois pas. En 1978, la Grande-Bretagne retourne dans Airbus, l'Espagne y est restée, et la grande commande d'Eastern Airlines invite à penser à un deuxième modèle. L' «Aérobus» 
français devient alors l'«Airbus» européen, mais face aux propositions «communautaires», les gouvernements choisissent la coopération transnationale pour construire l'Europe de l'aéronautique. Du point de vue historique, le lancement d'Airbus permet ainsi d'apercevoir la trajectoire d'un processus de construction européenne procédant entre intégration et coopération intergouvernementale.

\section{Wird Europa fliegen? \\ Der Start von Airbus und der Absturz einer ,gemeinschaftlichen“, aeronautischen Kooperation, 1965-1978}

Airbus ist nur eines von mehreren europäischen Kooperationsprojekten aus der zivilen und militärischen Luftfahrt der Sechzigerjahre. Um den führenden Amerikanern zu trotzen, kamen die nationalen Flugzeugindustrien nicht mehr umhin ,europäische Flieger“ zu bauen damit sie auch weiterhin eine Überlebenschance, sowohl produktions- als auch konzeptionsmässig hatten. Die transnationale Zusammenarbeit wird daher zu einer der wichtigsten Aktivitäten in einem Wirtschaftszweig der, gegen Ende der Sechziger, auch durch nationale Unternehmenskonzentrationen geprägt war. Die Abschwächung der amerikanischen Konkurrenz, die Weltwirtschaftskrise und der Beitritt Großbritanniens in die EWG beschleunigen dann in den Siebzigern die Debatte um den künftigen ,europäischen Flugraum“. Dieser „Gemeinsame Markt" der Aeronautik sollte von Aufträgen der zivilen Luftfahrtgesellschaften und der Luftstreitkräfte der Mitgliedsstaaten getragen werden. Das Vorhaben scheiterte allerdings. Die Rückkehr Großbritanniens zum Airbus im Jahre 1978, der Verbleib Spaniens im Projekt und ein Großauftrag der Eastern Airlines luden zum Nachdenken über ein zweites Modell ein. Aus dem französischen „Aérobus“ wurde sodann der europäische „Airbus“. Allerdings entschieden sich die Regierungen für das Modell einer transnationalen Kooperation um das aeronautische Europa aufzubauen. „Gemeinschaftlich“ ausgerichtete Pläne wurden fallengelassen. Insofern erlaubt es der Start von Airbus aus der historischen Perspektive heraus einen europäischen Entwicklungsprozess zwischen Integration und Kooperation der Regierungen zu erkennen.

\section{Dimitri Grygowski \\ The United States and European Monetary Unification, 1968-1998: an Assessment and New Research Perspectives}

This contribution aims at explaining the evolution of United States policy towards European integration through the case study of European monetary unification. It reassesses the influence which the United States had on the development of a common European monetary policy. Suggestions are made in the first part on the factors that explain the weaknesses of European monetary cooperation in the 1960s. It appears that other factors than purely intra-European dimensions slowed the process of cooperation and integration. In this respect, the study shows that the German monetary allegiance to United States was part of the complex German-American security relations. United States evaluation of European Monetary Integration has been ambivalent since its inception. Having gained momentum with America's emancipation from Bretton Woods's framework, EMU entered a phase of slow progress. The study shows how Washington perceived European monetary commitments primarily through its impacts on the reform and the balance of the international monetary system. In addition, this article points out that the Americans who in 1978 showed alarm and discomfort with the European Monetary System. We observe in the Department of Treasury practices a whole set of actions aiming at almost thwarting the EMS. However, with respect to the Euro, Americans reacted with almost indifference to the inception of the 
single currency. From that time on, it was the admittance of its de facto existence and only attempts to accommodate themselves to this new reality in the best interests of American business.

\section{Les Etats-Unis et l'unification monétaire de l'Europe: bilan d'ensemble et perspectives de recherche (1968-1998)}

Le présent article analyse l'évolution de la politique américaine vis-à-vis de l'intégration européenne à partir de l'exemple du projet d'Union monétaire européenne. Cette contribution souligne le rôle joué par les Etats-Unis à l'égard du développement d'une politique commune dans le domaine monétaire. La première partie s'intéresse aux facteurs qui permettent d'expliquer la faiblesse de la coopération monétaire européenne dans les années soixante, se focalisant notamment sur les facteurs extra-européens. L'analyse débouche sur un premier constat: l'allégeance de la RFA à la politique monétaire des Etats-Unis constituait l'un des ressorts des relations politiques et de défense germano-américaine. Les Etats-Unis firent preuve d'ambivalence dès les débuts de l'intégration monétaire européenne. Erigée en priorité de l'agenda européen après les actions d'émancipation américaine de l'ordre de Bretton Woods, l'UEM se distingue ensuite par une lente progression. L'étude montre que Washington a perçu les objectifs européens essentiellement à travers le prisme de leurs conséquences sur la réforme du système monétaire international. Ainsi, les négociations menant au système monétaire européen (SME) plongent l'administration américaine dans l'embarras, cette dernière prenant parfois le risque, via, le Département du Trésor de faire capoter le projet européen. Finalement, l'étude des réactions face à l'euro introduit à une autre variation de la politique américaine. Réagissant avec indifférence, l'Amérique s'efforce de s'adapter aux nouveaux équilibres du système monétaire international afin que ses milieux d'affaires puissent en tirer le plus grand bénéfice.

\section{Die Vereinigten Staaten von Amerika die die europäische Währungseinheit: Bilanz und Perspektiven der Forschung. 1968-1998}

Der Aufsatz beschäftigt sich mit der Problematik der us-amerikanischen Haltung gegenüber dem Projekt der Europäischen Währungsunion und der Rolle die die USA in diesem Zusaammenhang bei der Entwicklung einer gemeinsamen Politik gespielt haben. Der erste Teil befasst sich zunächst mit jenen, insbesondere externen Faktoren, welche die Schwäche der europäischen Zusammenarbeit auf dem Feld der Währungsunion in den Sechzigerjahren kennzeichneten. Die Analyse führt zu einer ersten Feststellung: die unterwürfige Anlehnung der bundesdeutschen an die amerikanische Währungspolitik war Teil der komplexen politischen und sicherheitspolitischen Beziehungen zwischen Bonn und Washington. Dabei war das amerikanische Auftreten in dieser Angelegenheit von Anfang an stets doppeldeutig. Erst nachdem die Amerikaner sich von der in Bretton Woods festgelegten Ordnung gelöst hatten, wurde die Währungsunion allmählich zu einer Priorität auf der europäischen Agenda. Der Aufsatz zeigt, dass man die europäischen Ziele in den Vereinigten Staaten allerdings hauptsächlich unter dem Gesichtspunkt der Konsequenzen für das Internationale Währungssystem betrachtete. Hier lässt sich nun die Erklärung finden weshalb die Verhandlungen über das Europäische Währungssystem (EWS) die amerikanische Verwaltung in Bedrängnis brachten und letztere, mit Hilfe des Department of Treasury, mehrfach versuchte das europäische Projekt zu durchkreuzen. Schließlich wird gezeigt wie mit der Einführung des Euro eine weitere, anders geartete Reaktion zum Tragen kommt. Die amerikanische Politik legte 
in der Tat eine ziemliche Gleichgültigkeit an den Tag, und versuchte lediglich sich dem neuen Gleichgewicht des internationale Währungssystems anzupassen damit die amerikanische Geschäftswelt den größten Nutzen aus der Einheitswährung auf dem alten Kontinent ziehen konnte.

\section{Guia Migani \\ The EEC and the UN Economic Commission for Africa: The Difficult Converging of Two Development Plans for the African Continent (1958-1963)}

After having gained independence, the African countries examined whether it was appropriate to work out and realize common development projects. In this context the EEC was at one and the same time a model and a factor of division. While the European Common Market was an example to imitate, the association to the EEC of some African countries was also seen as an obstacle to the unification of the continent. Within the Economic Commission for Africa (ECA), a regional body of the United Nations, a lively and very interesting debate took place among the Member States on Africa's prospects of development as well as on the part that the EEC might play on the continent. The aim of this article is to analyse the course of this debate going on between the Six, the independent African states and the African countries associated to the EEC. From this point of view, the ECA provides a particularly interesting background for such kind of analysis, because it was the first international organization where African countries could assert themselves against the European powers. Inside the ECA the African states could work out economic and social development projects that surmounted former colonial divisions and criticise or support the EEC action in Africa. Therefore, it was interesting to get to the core of this debate in order to understand how the EEC and its part in the development of Africa were perceived at the beginning of the sixties.

\section{La Communauté économique européenne et la Commission économique pour l'Afrique de l'ONU: la difficile convergence de deux projets de développement pour le continent africain} (1958-1963)

Après leur indépendance, les pays africains s'interrogent sur l'opportunité d'élaborer et de réaliser des projets communs de développement. Dans ce contexte la CEE est à la fois un exemple et un facteur de division. Si le Marché commun européen représente un exemple, l'association à la CEE d'un certain nombre de pays africains est perçue comme un obstacle pour la réunification du continent. Dans la Commission économique pour l'Afrique (CEA), est un organisme régional des Nations Unies, se déroule un débat animé et très intéressant sur les perspectives de l'Afrique et sur le rôle qu'y sera dévolu à la CEE. Le but de cet article est d'analyser le développement de ce débat entre les Six, les Etats africains indépendants et les pays associés à la CEE. De ce point de vue la CEA représente un cadre particulièrement intéressant pour mener ce type d'analyse parce qu'elle constitue la première organisation internationale où les Etats africains peuvent s'imposer aux puissances européennes. Dans ce lieu les Etats africains peuvent élaborer des projets de développement économique et social dépassant les anciens clivages coloniaux, et critiquer ou défendre l'action de la CEE. Il a paru ainsi intéressant d'aller au fond du débat pour voir comment étaient perçus l'image et le rôle de la CEE dans le développement de l'Afrique au début des années soixante. 


\section{Die Europäische Wirtschaftsgemeinschaft und die Wirtschaftskommission für Afrika der UNO: die schwierige Konvergenz zweier Entwicklungsprojekte für den afrikanischen Kontinent (1958-1963)}

Viele afrikanische Staaten fragten sich, nach dem sie die Unabhängigkeit erlangt hatten, ob es nicht sinnvoll wäre gemeinschaftliche Entwicklungspläne zu verwirklichen. Unter diesem Gesichtspunkt bildete die EWG sowohl ein nachahmenswertes Beispiel als auch den Anlass zur Spaltung. Letzteres gilt besonders für die Assoziierung zwischen der EWG und manchen afrikanischen Staaten: sie wird als ein Hindernis wahrgenommen, das die Vereinigung des schwarzen Kontinents erschwert. In der Wirtschaftkommission für Afrika (WKA), einem Regionalorgan der UNO, fand zwischen assoziierten und unabhängigen Staaten eine höchst animierte und interessante Debatte über Afrikas Zukunftsperspektiven und die Rolle der EWG statt. Ihre Analyse ist Inhalt des vorliegenden Beitrags der um so aufschlussreicher ist, da die WKA eigentlich das erste internationale Forum abgab, das den afrikanischen Staaten sowohl die Möglichkeit gab sich gegebenenfalls auch gegen die europäischen Mächte zu behaupten als auch wirtschaftliche und soziale, die alten kolonialen Spaltungen überwindende Entwicklungsprojekte auszuarbeiten. Durch die geäußerte Kritik bzw. den Lob an der Haltung der EWG lassen sich auf diese Weise das Bild und die Rolle der Europäischen Gemeinschaft im Rahmen der Entfaltung Afrikas in den frühen Sechzigerjahren vortrefflich illustrieren. 


\section{European Civil Society}

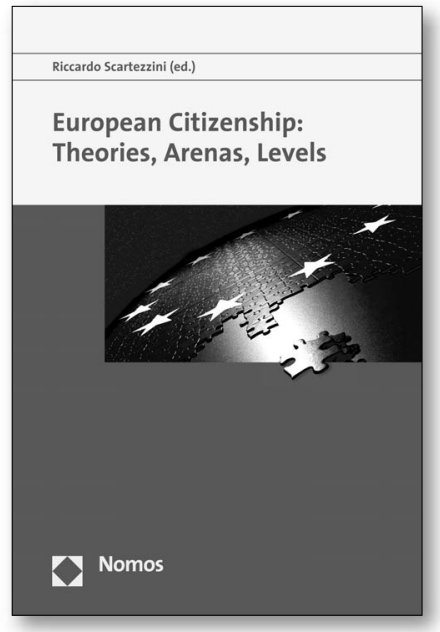

\section{European Citizenship:} Theories, Arenas, Levels By Riccardo Scartezzini 2007, $228 p p$., $p b$., 39,-€, ISBN 978-3-8329-2940-4
This book addresses the fundamental question of the social foundations of the European Union by looking at the concept of citizenship. It argues that citizenship, rather than identity, is the most promising anchor for developing a true European 'community of destiny' rather than just of policies. It begins by discussing the theoretical and normative underpinnings of this concept and by drawing the contours of a possible notion of citizenship when applied to a multi-level polity such as the European Union. It then explores the arenas within which such a notion may be practically shaped in a 'bottom-up' approach to the construction of citizenship rights, through more or less momentous choices made by actors both within and without European institutions. Finally it traces the historical roots of the concept of citizenship and explores the multiple levels at which it can be predicated, thus addressing the specific feature of the European Union of being a multi-level polity.

The reflections herein contained aim at providing guidance to the architects of European citizenship, be they active members of civil society as well as top-level decision-makers. 